\title{
Phenological models for implementing management practices in rain-fed avocado orchards ${ }^{1}$
}

\author{
Simone Rodrigues da Silva ${ }^{2}$, Tatiana Eugenia Cantuarias-Avilés ${ }^{2}$, \\ Bruno Chiavelli ${ }^{2}$, Michael Aleixo Martins ${ }^{2}$, Michelle Souza Oliveira ${ }^{2}$
}

\section{ABSTRACT}

Only a few phenological models have been formulated for rain-fed avocados in warm subhumid environments, and none of them have suggested crop management strategies for improving the trees performance in such conditions. The occurrence and intensity of major phenological events were assessed in 'Hass' and 'Margarida' avocado trees, in order to properly schedule the main crop practices for optimum management of rain-fed orchards in warm subhumid growing environments. Shoot growth, root density, number of open flowers, fruit set and fruit dropping rate were evaluated. For both cultivars, two shoot flushes were observed in SeptemberOctober (spring) and January-February (summer), while a maximum feeder root growth took place in late August, coinciding with flowering. Two other minor root growth flushes occurred after the onset of summer rains. Both cultivars had only one flowering period, followed by an intense fruitlet dropping. A second minor fruit dropping wave occurred in February (midsummer), for both cultivars. By determining the extent of each phenological phase in both avocado cultivars, it is possible to schedule applications of fertilizer, mulch and soil amendments, during the root growth flushes, as well as foliar sprays during shoot flushes, in order to maintain an adequate nutritional and sanitary status.

KEYWORDS: Persea americana Mill.; root growth; vegetative flush; fruit growth.

\section{INTRODUCTION}

Brazil is the ninth world's largest avocado producer, with over 165,000 tons harvested from 9,450 hectares yearly (FAO 2017). In 2014, the São Paulo state accounted for $53 \%$ of the national production (Agrianual 2017). Locally selected hybrids from West India and Guatemala, such as

\section{RESUMO}

Modelos fenológicos para a implementação de práticas de manejo em pomares não irrigados de abacateiro

Poucos modelos fenológicos têm sido formulados para abacateiros cultivados em sequeiro, em ambientes subúmidos cálidos, e em nenhum deles foram sugeridas estratégias de manejo do cultivo para melhorar o desempenho das árvores nessas condições. Avaliouse a ocorrência e a intensidade dos principais eventos fenológicos em abacateiros 'Hass' e 'Margarida', visando a programar práticas culturais apropriadas para otimizar o manejo de pomares não irrigados, em ambiente cálido e subúmido. Foram avaliados o crescimento de brotos, densidade da raiz, número de flores abertas, frutos fixados e taxa de queda de frutos. Para ambas as cultivares, observaram-se dois fluxos de brotação em setembro-outubro (primavera) e janeirofevereiro (verão), enquanto o crescimento máximo das raízes de absorção ocorreu no final de agosto, coincidindo com o florescimento. Dois outros fluxos de raízes, de menor intensidade, ocorreram após o início das chuvas sazonais de verão. Ambas as cultivares apresentaram apenas um período de floração, seguido por uma queda intensa de frutos. Uma segunda queda menor de frutos ocorreu em fevereiro (meados do verão), em ambas as cultivares. Ao determinar a extensão de cada fase fenológica em ambas as cultivares, é possível programar aplicações de fertilizantes, cobertura vegetal e corretivos ao solo, durante os fluxos de crescimento das raízes, assim como pulverizações foliares durante as brotações, para manter um estado nutricional e sanitário adequado.

PALAVRAS-CHAVE: Persea americana Mill.; crescimento radicular; fluxo vegetativo; crescimento de frutos.

'Geada', 'Fortuna', 'Quintal', 'Margarida' and 'Breda', are the main commercial cultivars.

In recent years, the 'Hass' cultivar has been established, due to an increasing demand in Europe. 'Hass' fruits are harvested from March to October, while 'Margarida' is a late-maturing cultivar, harvested from September to November and sold mainly domestically. 
Water deficit during flowering and fruit formation, as well as severe incidence of root rot, are the main problems limiting the expansion of avocado production in Brazil. Determining the periods of shoot and root flushing and flowering and fruit setting may assist in scheduling fertilization (Lovatt 2001), irrigation (Bárcenas-Ortega et al. 2007), pruning (Menzel \& Le Lagadec 2014), pest (Torres et al. 2012) and disease (Ávila-Quezada et al. 2002) control. Improved management practices may also optimize fruit quality and yield (Whiley et al. 1988a, Dixon et al. 2008, Menzel \& Le Lagadec 2014).

Several avocado phenological models have been previously developed (Whiley et al. 1988a, Wolstenholme \& Whiley 1989, Robinson et al. 2002, Cossio-Vargas et al. 2008, Dixon et al. 2008). In Brazil, two studies have described the vegetative flush, blooming and fruit growth periods for several cultivars, including 'Hass' (Oliveira et al. 2013, Silva et al. 2014). However, no specific management guidelines were recommended to growers.

The present study reports the phenological cycle of 'Hass' and 'Margarida' avocados under rain-fed conditions, in a warm, subhumid growing environment, in Brazil. Guidelines were provided on optimum tree management, based on the phenology of the two cultivars.

\section{MATERIAL AND METHODS}

The study was conducted in two commercial avocado orchards in Araras, São Paulo state, Brazil ( $22^{\circ} 24^{\prime} \mathrm{S}, 47^{\circ} 36^{\prime} \mathrm{W}$ and $611 \mathrm{~m}$ of altitude). Non-irrigated 'Hass' and 'Margarida' trees grafted on unknown seedling rootstocks were planted in December 2004 $\left(8 \mathrm{~m} \times 6 \mathrm{~m}\right.$, equivalent to 206 plants ha $\left.{ }^{-1}\right)$. The local climate is mesothermic (Cwa, according to Köppen), with a humid hot summer and a dry winter, with average daily maximum/minimum temperature of $32^{\circ} \mathrm{C} / 2^{\circ} \mathrm{C}$ and mean annual precipitation of $1,350 \mathrm{~mm}$, mostly concentrated between October and March. The soil was classified as a clayey Red Dystrophic Oxisol, deep and well drained, highly intemperized, acidic and with low natural fertility.

Phenological events were evaluated from August 2010 to July 2011, in ten trees of each cultivar. The reproductive growth was assessed on a panicle from the apical bud and on a panicle from a lateral bud, on each of the four branches tagged at the center of the canopy at the beginning of inflorescence elongation (one branch per quadrant, 8 panicles per tree), by weekly counts of open flowers and attached fruitlets. Fruit abscission was bi-weekly evaluated from full bloom ( $>50 \%$ open flowers) by counting the number of fruitlets dropped into four wooden boxes (40 $\mathrm{cm} \times 80 \mathrm{~cm}$ surface area) previously distributed in the quadrants under the canopy of each tree. Shoot length was assessed every two weeks on one shoot above the apical inflorescence and on one shoot above the lateral inflorescence ( 8 shoots per tree).

Root growth was measured every two weeks, in soil samples collected from 5 tagged trees of each cultivar, at four points under the canopy, distant $0.5 \mathrm{~m}$ from the trunk, using a stainless steel probe with $0.07 \mathrm{~m}$ in diameter, that was drilled into the soil to a depth of $20 \mathrm{~cm}$ (Silva et al. 2016). White and unsuberised feeder roots with $<5 \mathrm{~mm}$ width were washed out of the soil, dried and weighed. Root samples were then oven dried at $70-80{ }^{\circ} \mathrm{C}$, for $72 \mathrm{~h}$, and weighed. The results were expressed as grams of root dry matter per liter of soil (feeder root density). Meteorological data were recorded by an automatic weather station located at $5 \mathrm{~km}$ from the evaluation site.

Relative percentages of flowering, fruit setting and fruit dropping were calculated for each cultivar, from the proportion between flower or fruit count and the total number of flowers or fruits on the tagged shoots. Shoot growth rate (SGR) was calculated using the equation: $\mathrm{SGR}=\left(\mathrm{SG}_{2}-\mathrm{SG}_{1}\right) /\left(\mathrm{t}_{\mathrm{SG} 2}-\mathrm{t}_{\mathrm{SG} 1}\right)$, where $\mathrm{SG}_{1}$ and $\mathrm{SG}_{2}$ are the shoot lengths measured at times $\mathrm{t}_{\mathrm{SG} 2}$ and $\mathrm{t}_{\mathrm{SGl}}$, respectively. Average feeder root density was computed from the mean dry weight of roots present in 1-liter volume soil samples, individually collected in 10 plants per cultivar. The data were used to characterize the phenology of 'Hass' and 'Margarida' avocado trees.

\section{RESULTS AND DISCUSSION}

The occurrence and succession of main phenological events followed a similar pattern in rain-fed 'Hass' and 'Margarida' avocado cultivars, with two main shoot flushes (Figure 1A). The first flush occurred from mid-August (end of the dry winter period) to late October (spring), peaking in September for both cultivars. Average maximum and minimum temperatures during the period were $30{ }^{\circ} \mathrm{C} / 15^{\circ} \mathrm{C}$, with $109.6 \mathrm{~mm}$ of cumulative rainfall from August to October 2010 (Figure 1C). Two other 
smaller shoot flushes were observed on both cultivars from late November 2010 (spring) to mid-February 2011(summer) (Figure 1A).
In both cultivars, the flushing peak in midSeptember coincided with fruit setting (Figures 2A and $2 \mathrm{~B}$ ) and with the beginning of the rainy period

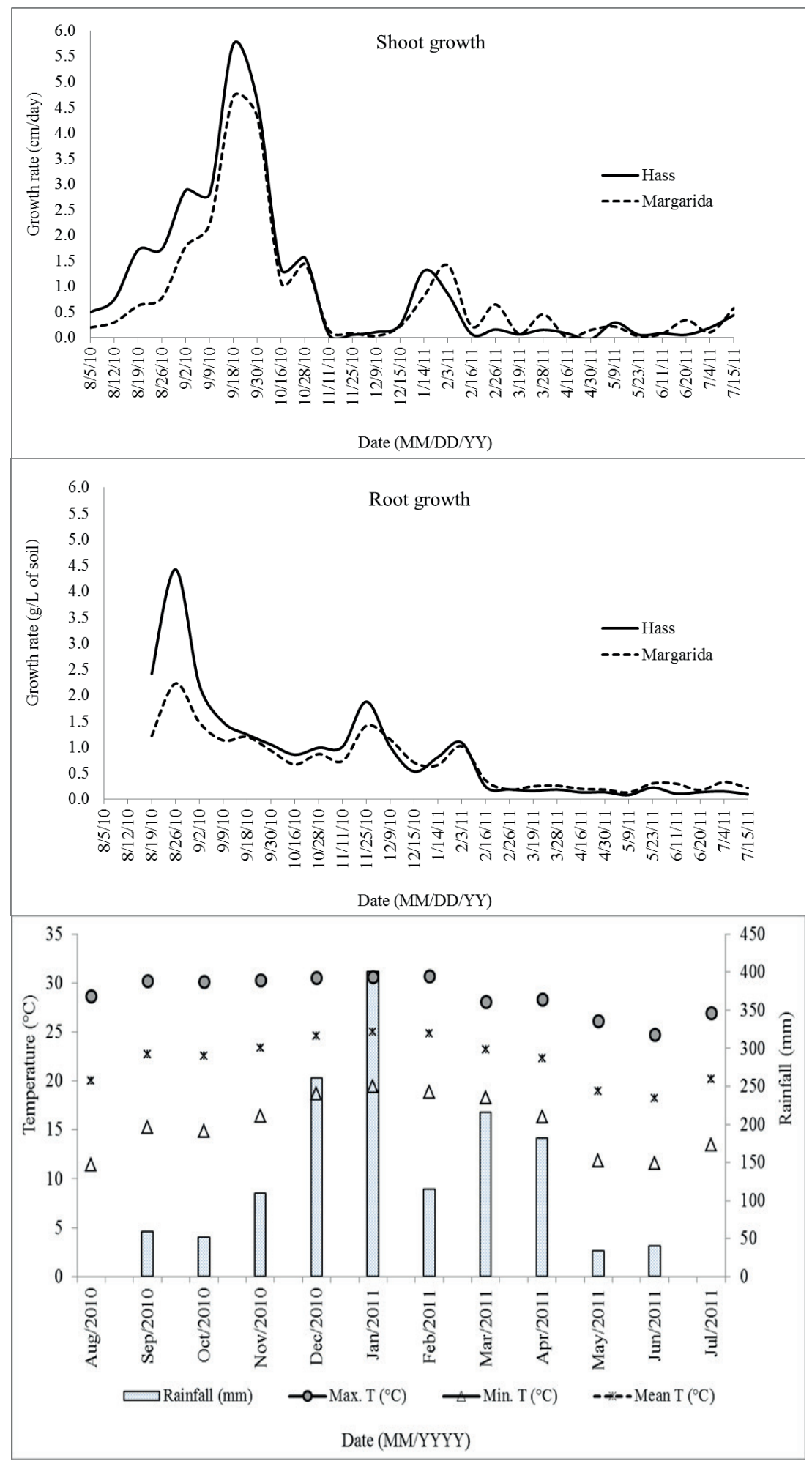

Figure 1. Seasonal patterns of shoot growth (A), root growth (B) and rainfall (C), maximum (Max. T), minimum (Min. T) and mean (Mean T) air temperature in rain-fed 'Hass' and 'Margarida' avocado orchards (Araras, São Paulo state, Brazil, 2010-2011). 
(Figure 1C). Two short periods of reduced growth occurred from late November to early December 2010 and from late May to mid-June 2011 (Figure 1A).

Two main shoot flushes were also reported by Cossio-Vargas et al. (2008) in rain-fed 'Hass' avocados grown on acidic soil, in warm Nayarit, Mexico. In contrast, Avilán et al. (2005) reported 2 to 4 flushes for several hybrids grown under rain-fed conditions, in the center-northern coastal region of Venezuela, under a tropical dry forest climate.

In São Bento do Sapucaí, in the São Paulo state (Cwb climate, $903 \mathrm{~m}$ of altitude), the first shoots emerged by mid-September in 'Hass' and in late September in 'Margarida', under maximum/ minimum temperatures of $20-21^{\circ} \mathrm{C} / 6-7^{\circ} \mathrm{C}$ (Oliveira et al. 2013). In avocado, the vegetative flush in spring competes with the young fruit for photoassimilates and water, and it is often associated with low yields (Whiley et al. 1988a).

The root growth pattern also followed a cyclical and expected pattern, with larger root densities in 'Hass' (Figure 1B), and a major flush was recorded for both cultivars in late August, during flowering, under cool and dry weather conditions (Figure 1C). Two minor root flushes were recorded for both cultivars by late November (Figure 1B), after the spring shoot flush, and from mid-January to early February, at the end of the summer shoot flush (Figure 1A).

Flowering occurred in August and September 2011 (Figures 2A and 2B). Average monthly minimum/ maximum temperatures were $28.7{ }^{\circ} \mathrm{C} / 11.4{ }^{\circ} \mathrm{C}$ in August and $30.2^{\circ} \mathrm{C} / 15.2^{\circ} \mathrm{C}$ in September (Figure 1C), being considered as optimum for avocado blooming (Salazar-García et al. 2013).

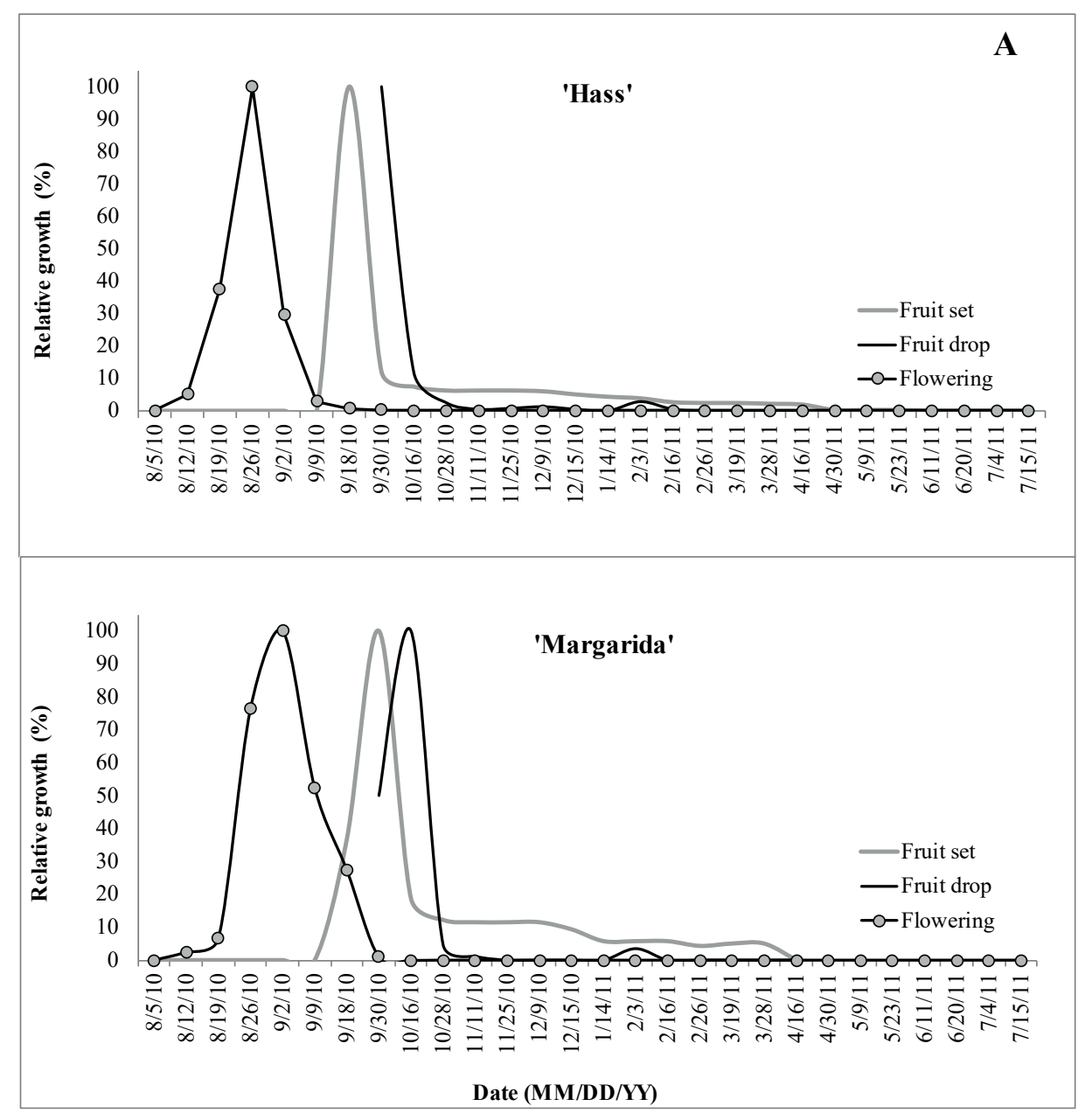

Figure 2. Seasonal patterns of flowering, fruit setting and fruit dropping for 'Hass' (A) and 'Margarida' (B) avocados grown under rain-fed conditions (Araras, São Paulo state, Brazil, 2010-2011). 
The flowering period lasted 42 days for 'Hass' (Figure 2A) and 56 days for 'Margarida' (Figure 2B). Flowering and the later shoot flush coincided with the main root flush (Figure 1B). This information will guide the selection of pollinator cultivars with overlapping flowering and determine the proper timing of beehive introduction for best pollination (Dixon et al. 2008).

The maximum fruit setting occurred at 23 and 28 days after the flowering peak in 'Hass' (Figure 2A) and 'Margarida' (Figure 2B), respectively, while the maximum fruit dropping occurred by late September in 'Hass' (Figure 2A) and in October for 'Margarida' (Figure 2B).

In this study, the root growth peak corresponded to blooming periods and, in both cultivars, it occurred earlier than reported in other countries, whereas the root flush peak always occurred after flowering (Whiley et al. 1988a, Wolstenholme \& Whiley 1989, Robinson et al. 2002, Cossio-Vargas et al. 2008, Dixon et al. 2008). The absence of rainfall in August, during the main root flush, hinders the fertilization of non-irrigated orchards. Therefore, the application of supplementary irrigation to orchards in late winter will support a maximum root activity, allowing soil fertilization during the flowering period and preventing environmental or nutritional stresses during this critical phenological stage (Bárcenas-Ortega et al. 2007).

Based on the occurrence and intensity of the different phenological stages determined in this study for both cultivars, regular cultural practices for avocado orchard management were scheduled (Figure 3). Variations in climatic conditions among years may lead to slight differences in the beginning and ending dates of the phenological events described in this study, which were defined based on observations collected during just one year. Nevertheless, this situation does not impede a correct scheduling of cultural traits during each phenological stage for both cultivars, considering that the shortest phase of fruit abscission may extend for a minimum of two to three weeks (Figure 2).

The shoot growth peak by mid-September should be correctly managed, in order to avoid its competition with fruit set. As bud breaking and flowering occurred simultaneously in both cultivars, nitrogen fertilizer applications should be judiciously supplied in this period, to avoid excessive shoot growth at the expense of fruit setting, or a poor flushing resulting in a smaller crop in the next season (Whiley et al. 2013, Menzel \& Le Lagadec 2014).

A higher absorption by new avocado leaves increases the efficacy of foliar fertilizers and plant growth regulators, when applied during flushing periods (Whiley et al. 1988a). Pesticide sprays should be also carefully scheduled during flushing, due to more frequent pest and disease outbreaks occurring in this period, as new leaves become more available and attractive to insects and pathogens (Ávila-Quezada et al. 2002, Torres et al. 2012).

The identification of root activity under local conditions will allow a correct timing for

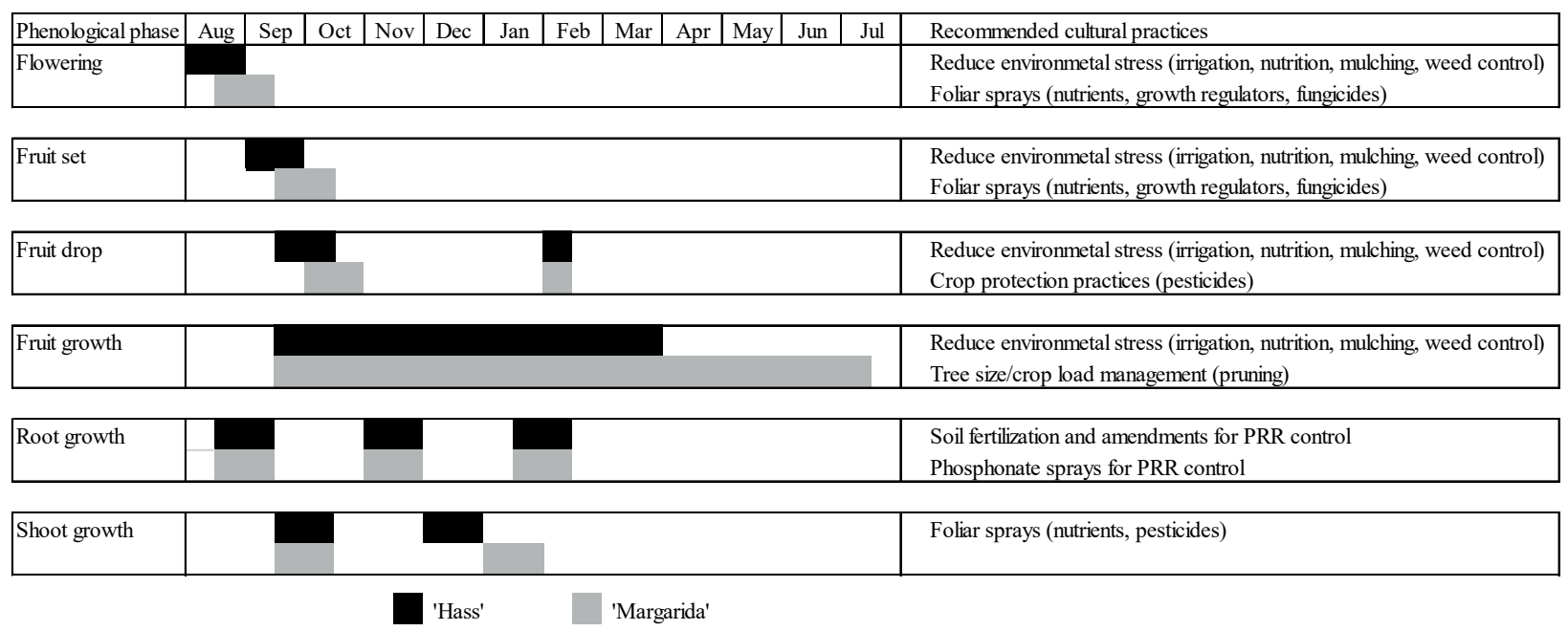

Figure 3. Schematic diagram of phenological stages of rain-fed 'Hass' and 'Margarida' avocados, as related with recommended cultural practices for each period, based on previous studies (Whiley et al. 1988a, Wolstenholme \& Whiley 1989, Whiley et al. 2013). 
soil applications of fertilizers, gypsum, lime and mulch (Whiley et al. 1988a), thus improving tree nourishment, soil moisture and temperature regulation, as well as soil microbiological activity against Phytophthora root rot (Mavuso 2009).

The determination of the flowering period duration will assist with the schedule of foliar sprays of triazoles at mid-anthesis, such as paclobutrazol and uniconazole, to increase fruit set and size by reducing the competition between reproductive and vegetative sinks developing simultaneously in the inflorescence (Whiley et al. 2013). Foliar sprayed paclobutrazol has also been reported to reduce plant stress in other woody species, such as shrubs, oaks and peanuts (Percival \& Albalushi 2007, Navarro et al. 2007, Sankar et al. 2007). The characterization of the flowering period will also allow the scheduling of pesticide applications oriented to protect both flowers and fruitlets from the attack of seasonal pests, such as Monalonion velezangeli (Torres et al. 2012), thrips and mites (Peña et al. 2013).

During flowering, stem carbohydrate reserves supporting the avocado reproductive and vegetative growth are depleted (Wolstenholme \& Whiley 1989, Liu et al. 1999). Consequently, in rain-fed orchards, soil fertilization strategies should be oriented to allow a high level of carbohydrate reserves in the trees in the autumn, in order to supply energy for flowering and fruit setting until the beginning of rains in spring. In California, extra-nitrogen soil applications in autumn increased fruit size and yield and reduced alternate bearing of 'Hass' avocados over a 4-year period (Lovatt 2001).

In addition, during the flowering and early fruit setting stages, avocado trees increase their water consumption rates (Whiley et al. 1988b), hence the use of supplementary irrigation may significantly reduce fruit abscission and increase fruit yield (Lahav et al. 2013). This is an important aspect, when managing non-irrigated avocado orchards in Brazil. Practices such as soil mulching and weed control will contribute to regulate the soil temperature and maintain a higher soil moisture in these critical periods (Mavuso 2009).

Effective irrigation management during flowering and fruit setting may reduce fruit dropping and increase final fruit size by preventing tree stress (Wolstenholme et al. 1990, Lahav et al. 2013), while the occurrence of drought or high air temperatures will significantly reduce fruit growth (Whiley et al.
2013). At earlier stages of fruit development, calcium applications to the soil improve fruit quality by increasing calcium root uptake and its accumulation in the pulp.

Fertilizer applications and soil amendments should be scheduled during root flushing to provide adequate nutritional and sanitary conditions to the trees (Whiley et al. 2013). During early fruit development stages in the rainy season, the application of an adequate fertilization program will promote a rapid fruit enlargement, because of the high rates of cell division and expansion during this phase (Salazar-García et al. 2013). In summary, the characterization of the main phenological phases for rain-fed 'Hass' and 'Margarida' avocados allows to determine the adequate timing of cultural practices for an optimum balance among shoot growth, fruiting and root growth, to ensure a high yield.

\section{CONCLUSIONS}

1. In central São Paulo State, Brazil, rain-fed 'Hass' and 'Margarida' avocados show a similar occurrence and succession of main phenological events, with two annual shoot flushes, three root flushes, one main flowering period and two fruit dropping events;

2. The main root growth recorded in late August, in both cultivars, corresponded to the flowering period. This is considered the ideal period for the adoption of strategies to manage root rot diseases, as well as supplementary applications of water and fertilizers, to support flowering and fruit setting.

\section{ACKNOWLEDGMENTS}

The authors would like to thank the Conselho Nacional de Desenvolvimento Científico e Tecnológico (Project CNPq 480736/2010-3), for financing this research, and the avocado growers from Bairro São Bento, in Araras, for allowing the use of their orchards. Special acknowledgements are given to Mr. Horst Bremer Neto, Mr. Antonio Pereira Goulart and Mr. Luiz Ferrari, from the Escola Superior de Agricultura "Luiz de Queiroz" (ESALQ), for technical support.

\section{REFERENCES}

AGRIANUAL 2017: anuário da agricultura brasileira. São Paulo: FNP, 2017. 
AVILÁN, L. et al. Comportamiento fenológico de híbridos guatemalteca por antillana de aguacate en la región centronorte costera de Venezuela. Agronomia Tropical, v. 55, n. 4 , p. 535-551, 2005.

ÁVILA-QUEZADA, G. et al. Dinámica espacio-temporal de la roña (Elsinoe perseae), el daño por trips y antracnosis (Glomerella cingulata) del aguacate en Michoacán, México. Revista Mexicana de Fitopatologia, v. 20, n. 1, p. 77-87, 2002.

BÁRCENAS-ORTEGA, A. E. et al. Influence of irrigation on the growth dynamics of roots of 'Hass' avocado trees. Proceedings of the Interamerican Society for Tropical Horticulture, v. 51, n. 1, p. 23-29, 2007.

COSSIO-VARGAS, L. E. et al. Fenología del aguacate 'Hass' en el clima semicálido de Nayarit, México. Revista Chapingo, v. 14, n. 3, p. 319-324, 2008.

DIXON, C. C.; HOFSTEE, B.; ELMSLY, T. A. 'Hass' avocado tree phenology 2004-2009 in the western bay of Plenty. New Zealand Avocado Growers' Association Annual Research Report, v. 8, n. 1, p. 35-57, 2008.

FOOD AND AGRICULTURE ORGANIZATION OF THE UNITED NATIONS (FAO). Faostat: production crops. 2017. Available at: <http://faostat3.fao.org/ browse/Q/QC/E/>. Access on: Mar. 03, 2017.

LAHAV, E.; WHILEY, A. W.; TURNER, D. W. Irrigation and mineral nutrition. In: SCHAFFER, B.; WOLSTENHOLME, B. N.; WHILEY, A. W. (Eds.). The avocado: botany, production and uses. 2. ed. Croydon: CABI, 2013. p. 301-341.

LIU, X. et al. 'Hass' avocado carbohydrate fluctuations: I. Growth and phenology. Journal of the American Society for Horticultural Science, v. 124, n. 6, p. 671-675, 1999.

LOVATT, C. J. Properly timed soil-applied nitrogen fertilizer increases yield and fruit size of 'Hass' avocado. Journal of the American Society for Horticultural Science, v. 126, n. 5, p. 555-559, 2001.

MAVUSO, Z. Effect of different mulch materials, composts and organic treatments on tree condition and root health. South African Avocado Growers' Association Yearbook, v. 32, n. 1, p. 6-9, 2009.

MENZEL, C. M.; LE LAGADEC, M. D. Increasing the productivity of avocado orchards using high-density plantings: a review. Scientia Horticulturae, v. 177, n. 1, p. 21-36, 2014.

NAVARRO, A.; SÁNCHEZ-BLANCO, M. J.; BAÑON, S. Influence of paclobutrazol on water consumption and plant performance of Arbutus unedo seedlings. Scientia Horticulturae, v. 111, n. 1, p. 133-139, 2007.
OLIVEIRA, M. C. et al. Fenologia e características físicoquímicas de frutos de abacateiros visando à extração de óleo. Ciência Rural, v. 43, n. 3, p. 411-418, 2013.

PEÑA, J. E. et al. Insect and mite pests. In: SCHAFFER, B. A.; WOLSTENHOLME, B. N.; WHILEY, A. W. (Eds.). The avocado: botany, production and uses. 2. ed. Croydon: CABI, 2013. p. 423-488.

PERCIVAL, G. C.; ALBALUSHI, A. M. S. Paclobutrazolinduced drought tolerance in containerized English and evergreen oak. Arboriculture \& Urban Forestry, v. 33, n. 6, p. 397-409, 2007.

ROBINSON, P. W. et al. Development of a phenological model of avocado tree growth for California. Acta Horticulturae, v. 575, n. 1, p. 859-864, 2002.

SALAZAR-GARCÍA, S.; GARNER, L. C.; LOVATT, C. J. Reproductive biology. In: SCHAFFER, B. A.; WOLSTENHOLME, B. N.; WHILEY, A. W. (Eds.). The avocado: botany, production and uses. 2. ed. Croydon: CABI, 2013. p. 118-167.

SANKAR, B. et al. Effect of paclobutrazol on water stress amelioration through antioxidants and free radical scavenging enzymes in Arachis hypogaea L. Colloids and Surfaces B: Biointerfaces, v. 60, n. 2, p. 229-235, 2007.

SILVA, F. O. R. et al. Fenologia reprodutiva e caracterização físico-química de abacateiros em Carmo da Cachoeira, Minas Gerais. Revista Ceres, v. 61, n. 1, p. 105-111, 2014.

SILVA, S. R. et al. Management of root rot in avocado trees. Revista Brasileira de Fruticultura, v. 38, n. 4, p. 1-5, 2016.

TORRES, L. F. T. et al. Relationship of Monalonion velezangeli Carvalho \& Costa (Hemiptera: Miridae) with the phenology of avocado (Persea americana Mill., cv. Hass). Revista de la Facultad Nacional de Agronomia, v. 65, n. 2, p. 6659-6665, 2012.

WHILEY, A. W. et al. Manage avocado growth cycles for productivity gains. Queensland Agricultural Journal, v. 114 , n. 1, p. 29-36, 1988a.

WHILEY, A. W.; CHAPMAN, K. R.; SARANAH, J. Water loss by floral structures of avocado (Persea americana cv. Fuerte) during flowering. Australian Journal of Agricultural Research, v. 39, n. 3, p. 457-467, 1988 b.

WHILEY, A. W.; SCHAFFER, B. A.; WOLSTENHOLME, B. N. Crop management. In: SCHAFFER, B. A.; WOLSTENHOLME, B. N.; WHILEY, A. W. (Eds.). The avocado: botany, production and uses. 2. ed. Croydon: CABI, 2013. p. 342-379.

WOLSTENHOLME, B. N.; WHILEY, A. W. Carbohydrate and phenological cycling as management tools for avocado orchards. South African Avocado Growers' Association Yearbook, v. 12, n. 1, p. 33-37, 1989. 